\title{
PReS13-SPK-1322: Autoinflammatory in nature: what patients teach us
}

\author{
M Gattorno \\ From 20th Pediatric Rheumatology European Society (PReS) Congress \\ Ljubljana, Slovenia. 25-29 September 2013
}

The autoinflammatory syndromes are a group of multisystem disorders characterized by recurrent episodes of fever and systemic inflammation affecting the eyes, joints, skin, and serosal surfaces. These syndromes differ from autoimmune diseases by several features, including the periodicity whereas autoimmune diseases are progressive, and the lack of signs of involvement of adaptive immunity such as association with HLA aplotypes, high-titer autoantibodies or antigen-specific $\mathrm{T}$ cells. Thus, autoinflammatory syndromes are recognized as disorders of innate immunity. This definition is supported by the a dramatic therapeutic response to IL-1 blocking. Indeed, the rapid and sustained response to a reduction in IL-1 activity on an "ex adjuvantibus" basis is the best hallmark of most of these diseases. Due to the rarity of these conditions, most of the studies aimed to unravel the pathogenic consequences related to the mutation of genes involved in inherited autoinflammatory diseases were based on the analysis of in vitro transfected cells or animal models. These approaches has the clear advantage to facilitate the availability of material for these studies and also to reduce the variability associated to clinical and genetic variables (type of mutation, active versus inactive disease, ongoing treatment, etc..). On the other hand the use of patients' primary cells strongly increase the possibility that the observed phenomena could be indeed pertinent to the pathogenesis of the disease and not influenced by possible artifacts linked to the study of transfected cells or animal models.

In the present lecture we will review the contribution that the study of primary cells from patients affected by inherited autoinflammatory diseases gave to the understanding of the role of IL- 1 in the pathogenesis of these disorders.

\footnotetext{
G Gaslini Institute, Genoa, Italy
}

(0) 2013 Gattorno; licensee BioMed Central Ltd. This is an Open Access article distributed under the terms of the Creative Commons Attribution License (http://creativecommons.org/licenses/by/2.0), which permits unrestricted use, distribution, and reproduction in any medium, provided the original work is properly cited. The Creative Commons Public Domain Dedication waiver (http://creativecommons.org/publicdomain/zero/1.0/) applies to the data made available in this article, unless otherwise stated.

\section{Disclosure of interest}

M. Gattorno Grant/Research Support from: Novartis, SOBI.

Published: 5 December 2013

doi:10.1186/1546-0096-11-S2-I14

Cite this article as: Gattorno: PReS13-SPK-1322: Autoinflammatory in nature: what patients teach us. Pediatric Rheumatology 2013 11(Suppl 2):114 Consultant for: Novartis, SOBI, Speakers Bureau: Novartis,
Submit your next manuscript to BioMed Central and take full advantage of:

- Convenient online submission

- Thorough peer review

- No space constraints or color figure charges

- Immediate publication on acceptance

- Inclusion in PubMed, CAS, Scopus and Google Scholar

- Research which is freely available for redistribution Submit your manuscript at
www.biomedcentral.com/submit C BioMed Central

\section{Biomed Central}

